\title{
Zwrot terenowy w serbskiej folklorystyce
}

Зоја Карановић, Јасмина Јокић (red.), Биље у традиционалној култури Срба. Приручник фолклорне ботанике, Универзитет у Новом Саду, Филозофски факултет, Нови Сад 2013, 288 s. Зоја Карановић (red.), Биље у традиционалној култури Срба. Приручник фолклорне ботанике II, Универзитет у Новом Саду, Филозофски факултет, Нови Сад 2014, 284 s.

Redakcyjny zamysł cyklu Биље у традищионалној култури Срба. Приручник фолклорне ботанике (Rośliny w kulturze tradycyjnej Serbów. Podręcznik botaniki ludowej) oraz jego merytoryczna zawartość są pochodną próby wyjścia serbskiej folklorystyki z pułapki badań gabinetowych, które po rozdzieleniu się dróg badaczy terenowych i gabinetowych zdominowały światowy dyskurs folklorystyczny i stały się jedną z głównych przyczyn utraty przez folklorystykę (jako dziedzinę nauki) ciągłości. Publikację omawianej serii prac zbiorowych poprzedziło otwarcie w 2012 roku na Wydziale Filozoficznym Uniwersytetu w Nowym Sadzie Centrum Badań Serbskiego Folkloru, którego pomysłodawczyni - Zoja Karanović - główny nacisk położyła na: 1) zbieranie nowego (aktualnego, „teraz” werbalizowanego) materiału źródłowego; 2) prowadzenie badań terenowych bez filologicznego obciążenia genologią, tj. skoncentrowanie się na nadawczo-odbiorczej specyfice i powtarzalności tekstu folkloru; 3) dydaktykę (szkolną i uniwersytecką, krajową i międzynarodową) field research realizowaną z pomocą etnografów i antropologów; 4) umiędzynarodowienie rezultatów badań oraz stworzenie sieci wymiany informacji dla badaczy z zagranicy zajmujących się serbskim folklorem.

Tak zaprojektowany fundament programowy skutkował przeniesieniem punktu ciężkości z teorii na praktykę. Zanim więc doszło do spotkania na pierwszej konferencji naukowej (Wspótczesna serbska folklorystyka, Uniwersytet w Nowym Sadzie, 4-5.10.2013), folkloryści wzięli 
udział w dwóch cyklach badań terenowych połączonych z pracą dydaktyczną. Pierwszym z nich była Letnia Szkoła Serbskiego Folkloru (11-18.07.2013), drugim wywiady pogłębione prowadzone w miejscowościach zlokalizowanych w paśmie górskim Stara Planina i okolicy Knjiaževaca (7-9.2013). Efektem obu spotkań są dwie inicjalne części referowanego cyklu, służące jednocześnie jako podręczniki dla uczestników drugiej Letniej Szkoły Serbskiego Folkloru (6-20.07.2014).

Wspomniane tomy łączy tematyczne zorientowanie na problematykę roślinną w serbskich tekstach folkloru. Przy czym pod pojęciem rośliny, podobnie jak w monografii Stanisława Kobielusa, kryje się „zarówno drzewo, kwiat, owoc, jak też ich zapach, kolor i inne elementy rzeczywiste czy metaforyczne, które ułatwiają szersze spojrzenie na przyrodę" (Kobielus 2006: 9). Artykuły naukowe oraz zamieszczone jako aneksy antologie źródeł (rezultaty wzmiankowanych badań), związane są bezpośrednio ze światem florarium i podporządkowane postulatom założycielskim Centrum. Odnajdziemy w nich (krytyczne!) wylistowanie opatrzonych już rangą historyczną wierzeń związanych z florą, a wyrażających się w praktyce obrzędowo-magicznej oraz w twórczości słownej. Umożliwia to uczniom/ studentom/pracownikom naukowym wytyczenie podstawy do badań/spisywania współcześnie rejestrowanych kultów roślinnych i sposobów sprawczego wykorzystania „wiedzy roślinnej” (w funkcji stwarzającej i niszczącej) w lecznictwie ludowym. Należy jednak podkreślić, że obok celów przyświecających podręcznikowi (podstawowe źródło wiedzy) i wytyczających informacyjno-dydaktyczny sposób czytania prac składających się na omawiany cykl, jest on także adresowany do czytelników świetnie zorientowanych w problematyce folklorystycznej. Jeśli wziąć bowiem pod uwagę zakresy bibliografii podmiotowych i przedmiotowych oraz wykorzystane metody badawcze i osiągnięte rezultaty, wszystkie artykuły przekraczają swój pierwotny cel i stają się ważnym studium problemowym oraz wskaźnikiem swoistej etyki i poetyki flory w tradycyjnej serbskiej kulturze.

Odpowiedzią na ostatni z fundacyjnych aksjomatów Centrum, a mianowicie konieczność umiędzynarodowienia wyników eksploracji naukowych poświęconych serbskiemu folklorowi, jest dwujęzyczność tomów. Każdy z nich podzielono na dwie części: serbską i jej angielski odpowiednik wydrukowany jako odwrócony rewers. Odczuwalny jest jednak brak autorów afiliowanych w zagranicznych placówkach badawczych. Tę 
nieobecność ma przełamać właśnie przygotowywany tom trzeci będący, w pierwotnym założeniu, kolejną częścią Podręcznika botaniki ludowej, tym razem adresowanym do uczestników trzeciej Letniej Szkoły Serbskiego Folkloru. Niestety, zaplanowane w jej ramach badania terenowe zostały odwołane, a redagowane prace tracą funkcje podręcznikowe. Pozostaje jedynie nadzieja na podtrzymanie rozpoczętej współpracy międzynarodowej, która skutkować ma wymianą doświadczeń badawczych zorientowanych na serbskie źródła folklorystyczne.

Czytelnik sięgający po Podręczniki musi być przygotowany na brak podziału tematycznego wewnątrz publikacji. Interesującej go pracy szuka więc po nazwisku autora (nie ma kolejności alfabetycznej) lub tytule, który nie zawsze jest precyzyjny i wskazujący na zakres/cel kryjącej się pod nim analizy. Ponad połowa (siedem) z trzynastu autorek prac opublikowanych w dwóch pierwszych tomach roślinnego cyklu to badaczki obecne w obu częściach. Na ich przykładzie możemy zaobserwować początek procesu rozwoju zainteresowania problematyką roślinną i jego eksploracyjne ukierunkowanie.

Programową drogę wytycza wspomniana już Zoja Karanović, która, tworząc studia problemowe wybranych gatunków roślin (t. 1: $O$ здравиy. Мит, обред, магија, поезија [O bodziszku korzeniastym. Mit, obrzęd, magia, poezja]; t. 2: Значена и функиије купине у традиционалној култури Срба и Словена [Znaczenia i funkcje jeżyny w tradycyjnej kulturze Serbów i Słowian]), wskazuje na źródłowe (zwrot ku źródłom wytworzonym w czasie badań terenowych) i metodologiczne możliwości takiej orientacji badawczej. W dwóch pierwszych tekstach skupia się na mitycznym, obrzędowym, magicznym i poetyckim wykorzystaniu bodziszka korzeniastego oraz jeżyny w serbskiej i słowiańskiej tradycyjnej oraz współczesnej kulturze ludowej. Dopiero w trzeciej pracy, napisanej we współautorstwie z Vesną Đukić, odchodzi od gatunkowych monografii i fundamentem rozważań czyni teksty folkloru słownego (t. 2, Песме с мотивима биља и растиња забележене у торлачким селима око Белог Тимока [Pieśni z motywami roślinnymi zapisane we wsiach Torlaków w okolicy Białego Timoku]). Tą drogą podąża także Mirjana Stefanović, która w artykule (t.1) Јавор у српској култури (Jawor w serbskiej kulturze) analizuje typowe (ogólnoświatowe) i specyficzne (charakterystyczne dla serbskiej kultury ludowej) cechy jawora jako przedmiotu kultu. Także w kolejnym 
tekście: (t.2) Посвећујем ове струкове смиља, ковиља и чубра (Ofiarowuję te naręcza kocanek, ostnicy i cząbru) pozostaje w kręgu problematyki gatunkowej (roślinnej) analizowanej na szerszym tle symboliki kulturowej.

Roślinne zorientowanie gatunkowe kontynuuje Danijela Popović (t. 1: Крушка у традиционалној српској култури и усменој прози [Grusza/gruszka w serbskiej kulturze tradycyjnej oraz w prozie ludowej]; t. 2: Растиње и биље у демонолошким предањима [Roślinność opowiadań demonologicznych]), która poszukuje zależności między gatunkiem botanicznym a genologią folkloru słownego. Źródłową i metodologiczną precyzję proponuje Tatjana Vujnović, której teksty (t. 1: Функције и значења биља у сватовским песмама Вукове збирке [Funkcje i znaczenia roślin w pieśniach weselnych ze zbioru Vuka Stefanovicia Karadžicia]; t. 2: Употреба биља у ритуалима око рођења детета на примеру Јужне Србије) [Wykorzystanie roślin w rytuałach narodzinowych na przykładzie południowej Serbii]) idealnie spełniają podręcznikową funkcję informacyjno-dydaktyczną, a jednocześnie przekraczają tę rolę i stanowią świetnie napisane artykuły naukowe. Znamienne jest tu położenie punktu ciężkości nie na świecie roślin a czynności obrzędowej, w której jest wykorzystywany. Zorientowanie na gatunek poetycki, a nie roślinny, obserwujemy także u Snežany Samardžiji (t. 1: Из хербаријума српских народних приповедака. Веровања о биљкама и жанровски систем [Z herbarium serbskich bajek ludowych. Wierzenia roślinne i system gatunkowy]; t. 2: Танковрха јела и зелен бор. Напомене уз зимзелено дрвеће у народној nоезијu [Cienko zwieńczona jodła i zielona sosna. Przyczynek do roślin zimozielonych w poezji ludowej]). Silne zorientowanie terenowe przedstawiają natomiast niezwykle ważne, zwłaszcza w kontekście dydaktycznym, prace Biljany Sikimić (t. 1: Како читати загонетке. Еротски свет културних биљака [Jak czytać zagadki? Erotyczny świat roślin kulturowych]; t. 2: Како разговарати о биљкама? [Jak rozmawiać о roślinach?]; Антрополошко-лингвистички речник лековитог биља: Кюажеваи и околина [Antropologiczno-lingwistyczny słownik roślin leczniczych: Knjaževac i okolica]).

W odróżnieniu od wymienionych autorek Jasmina Jokić - ostatnia $\mathrm{z}$ badaczek obecna $\mathrm{w}$ obu tomach - proponuje ujęcia przeglądowe, w których odchodzi od aktualnie prowadzonych badań terenowych na 
rzecz materiałów zastanych (t. 1: Свето и демонско дрвеће у српској фолклорној традицији [Święte i demoniczne drzewa w serbskiej tradycji folklorystycznej]; 2: Исиелитељска моћ светог дрвећа [Lecznicza тос świętych drzew]). Przy tak szeroko zaprojektowanych polach eksploracji, a jednocześnie ograniczonych objętościowo „możliwościach” artykułu, trudno jest wytyczyć zakres materiału źródłowego. Problem zostaje wskazany a perspektywy jego analizy sformułowane. Dalsze rozważania czekają na formę książkową.

Ostatnie pięć ważnych głosów w roślinnym dyskursie opartym na serbskich źródłach folklorystycznych to prace: Mirjany Detelić, Nedy Mimicy Dukić, Nataszy Poloviny, Sonji Petrović, Mileny Milošević Micić. Wpisują się one $\mathrm{w}$ realizowany $\mathrm{w}$ recenzowanych tomach program Centrum i odpowiadają na dydaktyczno-naukowo-terenowy postulat założycielski. Jednocześnie każda z nich zadaje nowe pytania eksploracyjne i tym samym otwiera nowe drogi badawcze, którymi może podążać roślinny dyskurs. Mirjana Detelić (t.1: Гроб у гори. Садејство просторног и биљног кодирања у епици [Grob na górze. Współdziałanie przestrzennego i roślinnego kodowania w epice]) wskazuje na poszczególne gatunki roślin jako markery nagłej śmierci bohatera epickiego i ofiarę poniesioną za zbawienie jego duszy. Motyw ofiarny organizuje także analizy Sonji Petrović (t. 2: Причешћивање биљем и плодовима дрвећа [Komunia pod postacią roślin i owoców drzew]) i Mileny Milošević Micić (t. 2: Свето дрво запис као окосница дрвећа [Święte drzewo - zapis jako szkielet drzew]), które szukają odpowiedzi na pytanie o współczesne (na postawie aktualnie prowadzonych badań terenowych) miejsce florarium w formach osobistej i kolektywnej pobożności. Dyskursywnym przedłużeniem ich rozważań jest antologia tekstów wykorzystywanych m.in. w czasie leczenia za pomocą roślin (t. 1: Свет флоре у веровағу, причи, песми, магијској пракси и лечеґу [Świat roślinny w wierzeniach, opowieściach, pieśniach, praktyce magicznej i leczeniu]) oraz artykuł Nedy Mimicy Dukić (t. 1: Исиелитељска моћ биља и фитотерапија данас [Lecznicza moc roślin i fitoterapia dzisiaj]). Folklorystyczny dialog przekracza jedynie praca Nataszy Poloviny (t. 2: Симболика крина у српској средњовековној књижевности [Symbolika lilii w serbskiej literaturze średniowiecznej]), która, pozostając w problemowym kręgu botaniki, materiałem źródłowym czyni tekst literatury pisanej. 
Podsumowując powyższe uwagi, należy podkreślić, że dwa pierwsze tomy omawianej publikacji spełniają, w moim przekonaniu, zadania stawiane podręcznikowi. Odpowiadają bowiem aktualnemu stanowi wiedzy z danej dyscypliny i zawierają deskrypcję co najmniej najważniejszych metod badawczych. Nie zamykają oczywiście listy możliwych pytań tak dydaktycznych, jak i badawczych. Przy otwartej formule folklorystyki i szerokim definiowaniu folkloru jest to zresztą zadanie nie tyle trudne, co karkołomne. W sukurs przychodzi jednak redaktorkom poetyka zbioru, która odpowiada postulowanemu na Słowiańszczyźnie Południowej dialogowi folklorystycznemu, w którym głos mają zarówno tęsknota za tożsamością wynikająca z pragnienia bezpieczeństwa traconego przez narastające poczucie niepewności oraz troska o społeczne uznanie (cf. Bauman 2004: 13-14 i 2007; Markowski 2013) (przede wszystkim jako reakcja na głosy naukowców spoza słowiańskich Bałkanów), jak i - posługując się sugestywnym językiem Odo Marquarda - niezgoda na ,perfekcjonizm, będący właściwym wrogiem interdyscyplinarnej rozmowy" oraz dążenie do produktywnego nieporozumienia, umiejętność dziedzinowej egzystencji „,z otwartymi aporiami i naddatkami rozbieżnych sensów” (Marquard 1994: 116-117).

Joanna Rękas

\section{Literatura}

Bauman Z., 2004, O tarapatach tożsamości w ciasnym świecie, w: Dylematy wielokulturowości, red. W. Kalaga, Kraków, s. 13-39.

Bauman Z., 2007, Tożsamość. Rozmowy z Benedetto Vecchim, przeł. J. Łaszcz, Gdańsk. Czubalina M., Czubała D., 1988, Refleksje paremiologiczne, w: Z problemów badania kultury ludowej, red. T. Kłak, Katowice.

Kobielus S., 2006, Florarium christianum. Symbolika roślin - chrześcijańska starożytność i średniowiecze, Kraków.

Markowski M.P., 2013, Polityka wrażliwości. Wprowadzenie do humanistyki, Kraków. Marquard O., 1994, O nieodzowności nauk humanistycznych, w: idem, Apologia przypadkowości, przeł. K. Krzemieniowa, Warszawa. 